\title{
Reflective Practice in Healthcare Education: An Umbrella Review
}

\author{
Konstantinos C. Fragkos \\ Institute of Education, University College London, 7 Hartley House, Chambers Street, London SE16 4EP, UK; \\ constantinos.frangos.09@ucl.ac.uk; Tel.: +44-7960-340-489
}

Academic Editor: James Albright

Received: 14 February 2016; Accepted: 9 August 2016; Published: 11 August 2016

\begin{abstract}
Reflection in healthcare education is an emerging topic with many recently published studies and reviews. This current systematic review of reviews (umbrella review) of this field explores the following aspects: which definitions and models are currently in use; how reflection impacts design, evaluation, and assessment; and what future challenges must be addressed. Nineteen reviews satisfying the inclusion criteria were identified. Emerging themes include the following: reflection is currently regarded as self-reflection and critical reflection, and the epistemology-of-practice notion is less in tandem with the evidence-based medicine paradigm of modern science than expected. Reflective techniques that are recognised in multiple settings (e.g., summative, formative, group vs. individual) have been associated with learning, but assessment as a research topic, is associated with issues of validity, reliability, and reproducibility. Future challenges include the epistemology of reflection in healthcare education and the development of approaches for practising and assessing reflection without loss of theoretical background.
\end{abstract}

Keywords: reflection; healthcare education; umbrella review

\section{Introduction}

The healthcare sciences encompass professions that have a basis in scientific knowledge. Based on Glazer [1], these professions are "either based directly on science or contain a high component of strictly technological knowledge based on science in the education which they provide". According to technical rationality, practitioners of these professions are viewed as technical problem solvers who manipulate available techniques to achieve selected objectives in the face of manageable constraints. An objective function measures performance, a set of possible strategies of action and a range of techniques of implementation. In this context of scientific healthcare knowledge, Schön [2] suggested that practitioners need a new epistemology of practice: one that explains how competent practitioners engage and how professional knowledge develops. His inquiry is not arbitrary and is rooted in observed inadequacies and presuppositions held by current institutions. That is, Schön [2] was uneasy with the epistemic injustice occurring.

All healthcare professionals (e.g., doctors, nurses, physiotherapists, occupational therapists, social workers, and psychologists) have regulatory bodies that position education as one of the cornerstones of professional development. Learning is a dynamic process in which theories are constantly challenged and new theories frequently emerge; learning can range from gaining knowledge, skills, and competence, to behaviours, to practice and continuing professional development. Frenk et al. [3] provided insight into the reasons for this process, stating that health is about people and that the core purpose of professional education must be to enhance health system performance to meet the needs of patients and populations equitably and efficiently. However, the evidence has long shown a mismatch between professional competencies and patient and population priorities, resulting from fragmentary, outdated, and static curricula that produce ill-equipped graduates from underfinanced institutions. 
Traditional causes of this mismatch include curricular rigidity, professional silos, static pedagogy, insufficient adaptation to local contexts, and commercialisation of professions [3]. Moreover, a unifying consensus among teaching and learning theories in healthcare education is lacking, with a paucity of comparisons between existing theories, occasional discontinuity, and unaligned views of theory and practice [4]. Numerous reasons exist to explain this disparity, with the most notable being the multitude of healthcare professions. The societal role of healthcare professionals, whose purpose is to look after the health of people and populations, is another factor, in addition to the critical relationship between health, society, and individuals. Hence, healthcare professionals should apply a systematic approach to learning and must accept that education and pedagogy are not always aligned [3-5].

Kauffman and Mann [6] provide an outline of mainstream learning theories in healthcare education, which include adult learning principles, social cognitive theory, reflective practice, transformative learning, self-directed learning, experiential learning, situated learning, and learning in communities of practice. The current paper examines reflective practice in healthcare education, which was highlighted in the 1980s in seminal texts by Donald Schön [2,7] (mentioned above) and his well-known quote "inherent in the practice of the professionals we recognize as unusually competent, is a core of artistry" [7]. Reflective practice has become popular in the scientific literature, with more than 500 publications in 2014 and in 2015 (Figure 1). Numerous empirical studies have investigated various aspects of reflective practice in healthcare education. Researchers have also conducted extensive reviews, including several systematic reviews. In this context, a mapping of the literature via an umbrella review is needed.

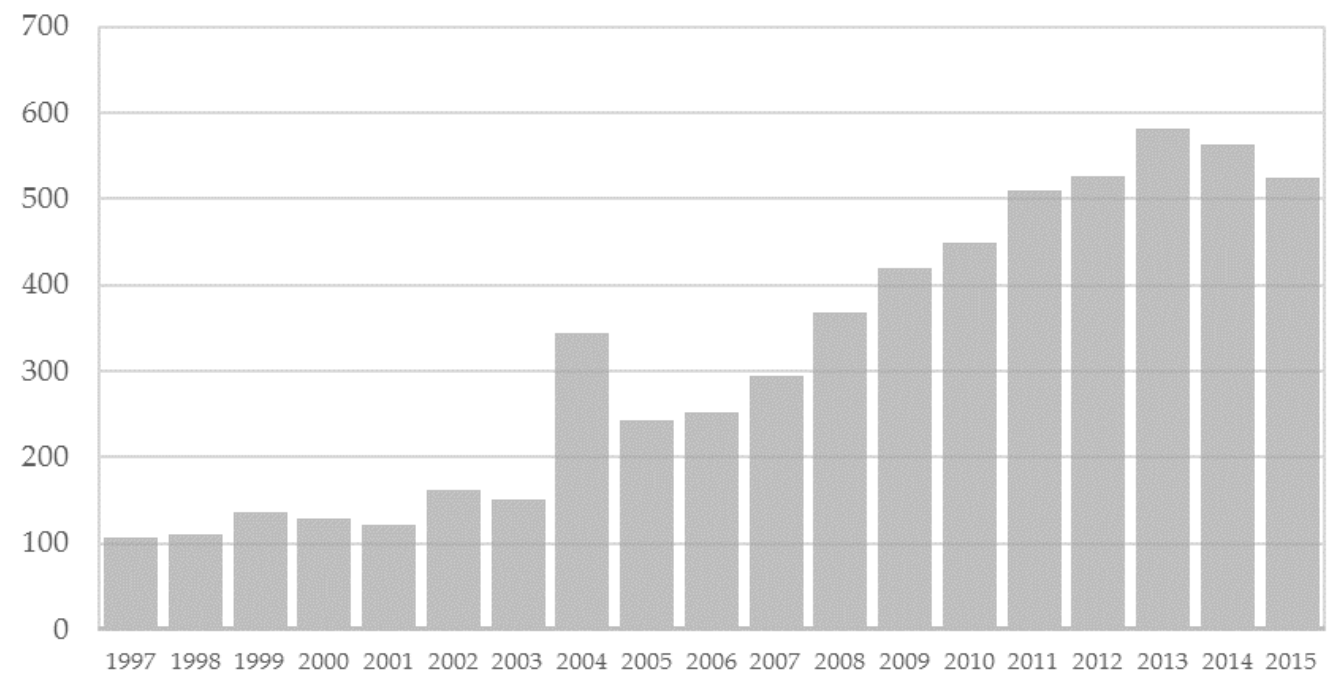

Figure 1. Papers published per year related to reflection in the healthcare education literature. The results are from the Web of Knowledge database, with a search for reflection or reflective in the title and the topic of education.

Umbrella reviews are a method of locating, appraising, and synthesising systematic review-level evidence [8,9]; that is, compiling evidence from multiple reviews into one functional document. The current review methodology is informed by the guidelines of The Joanna Briggs Institute [10]. Using an umbrella review methodology is recommended when addressing issues with a broad scope and issues associated with potentially contradictory or divergent findings.

The current study aims to answer the following questions:

1. Which models and definitions of reflection and reflective practice are in use?

2. How does empirical research depict reflective practice in healthcare education (the design and evaluation of education interventions)?

3. What are the future directions of reflective research and practice in healthcare education? 


\section{Materials and Methods}

\subsection{Identification of Relevant Studies}

Electronic literature databases (EMBASE, CINAHL, PubMed, Scopus, Google Scholar, Web of Knowledge) were searched to identify relevant reviews (including critical, narrative, and systematic reviews, as well as meta-analyses) of reflection in healthcare education published from 1 January 1950 until 31 January 2016. The inclusion criteria for papers were as follows: (i) they described a review or meta-analysis and reported the literature search method (systematic or non-systematic); (ii) they reported on studies performed in healthcare settings that involved any type of educational theme with respect to reflective practice; and (iii) they were published in English. Reviews were excluded if they were simply narrative and did not indicate any methodology. Identified papers were first screened for inclusion based on the title, followed by a screening of the abstract and then the full text. The reference lists of included papers were screened for further relevant studies. Any duplicate papers were removed. Grey literature (literature that is not formally published in sources such as books or journal articles) was not considered for inclusion in this review.

\subsection{Search Method, Data Extraction, and Quality Assessment}

The following keywords were used in the literature searches: reflection, reflective practice, education, healthcare, and review. For example, the following exact search method was used in PubMed: ((((reflection [Title/Abstract] OR reflective [Title/Abstract])) AND (education [Title/Abstract] OR learning [Title/Abstract] OR evaluation [Title/Abstract] OR student [Title/Abstract] OR practice [Title/Abstract] OR professionals [Title/Abstract]))) AND (systematic review [Title/Abstract] OR literature review [Title/Abstract] OR narrative review [Title/Abstract] OR critical review [Title/Abstract]).

From each individual review, the following information was obtained: objectives, the number of included studies, inclusion and exclusion criteria, and findings. Where possible, the findings were categorised with respect to the design and evaluation of educational interventions, the level of learners and the profession. Quality assessment was conducted with the AMSTAR (Assessing the Methodological Quality of Systematic Reviews) instrument [11,12], which assesses the key domains of a systematic review, first by identifying whether the research question and inclusion criteria were established before conducting the review. Next, this method involves examining whether the study included data extraction by at least two independent researchers and a comprehensive literature review with searches of at least two databases. The final step involves examining whether a detailed list of included/excluded studies is reported, quality assessment in analysis is performed and all of the above information is reported in the conclusion of the review [8].

\subsection{Theoretical Stance}

The current study assumes that the methodology and expectations for research tend towards the side of positivism and that they are grounded in empiricism. An attempt to avoid an interpretive stance is made, with the recognition, however, of the possible difficulties with this approach, given that reflection has a strong interpretive and phenomenological base given the challenging nature of objectively describing an inherently subjective topic [13-15]. Limitations are discussed at the end of the article, but every effort was made to ensure the reliability of the findings by adopting a descriptive approach with quality assessment of the studies included in this review. 


\section{Results}

\subsection{Description of Studies}

Nineteen reviews satisfying the inclusion criteria were identified (Figure 2) [16-35]. These reviews are presented in Table 1. They include systematic and non-systematic reviews that examined reflective practices in medical, nursing, therapy, and healthcare professions. The learner level was undergraduate, graduate, or postgraduate. The focus of these studies included an analysis of reflective practice in educational design, evaluation and assessment; a thematic analysis of the literature with respect to theory building; or the definition of reflective practice in relation to beliefs, attitudes, and behaviours. Relevant discussions and other review articles were also considered, but were not included in this umbrella review [36-51].

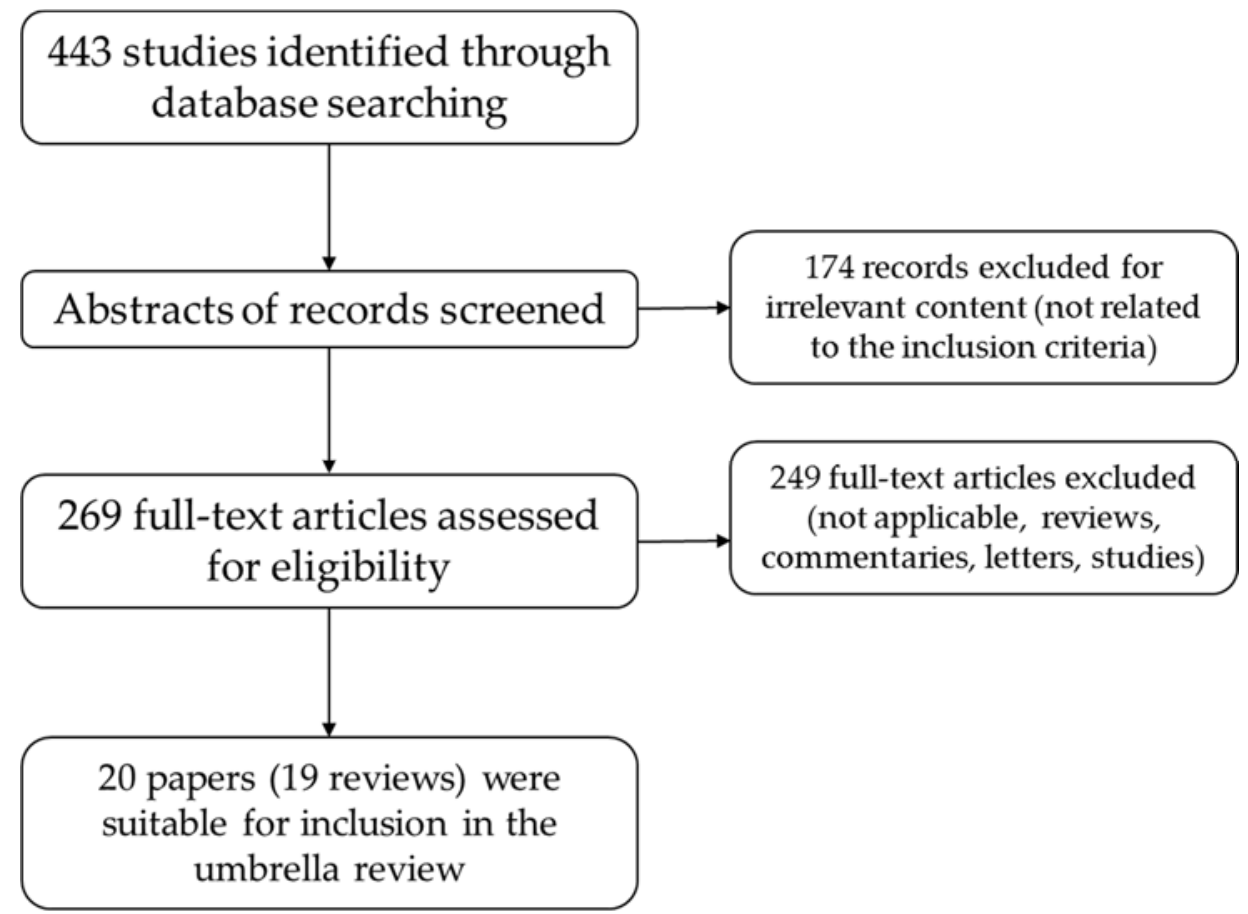

Figure 2. Flowchart of search results. 
Table 1. Studies included in the umbrella review.

\begin{tabular}{|c|c|c|c|}
\hline Authors & Objective and Methods & Summary of Findings & AMSTAR Score \\
\hline Williams [16] & $\begin{array}{l}\text { Objective: To explore the influence of current learning traditions in } \\
\text { nursing on the development of reflection and critical reflection as } \\
\text { professional practice skills and to offer suggestions for nursing } \\
\text { education for development of critical reflection. } \\
\text { Organizational constructs: Mezirow's transformative learning theory, } \\
\text { Barrows conceptualization of problem-based learning. Integrative } \\
\text { literature review of published literature related to nursing, health } \\
\text { science education and professional education from 1983-2000. }\end{array}$ & $\begin{array}{l}\text { Level of education: undergraduate, graduate, postgraduate } \\
\text { Learner profession: nursing } \\
\text { Findings: Specialized knowledge is clearly essential for professional practice; } \\
\text { Self-consciousness (reflection) and continual self-critique (critical reflection) } \\
\text { are crucial to continued competence. } \\
\text { Strategies to facilitate reflection have been outlined in the literature, specific } \\
\text { strategies to facilitate the development of critical reflection are less described. } \\
\text { Development of these abilities should be linked to professional development } \\
\text { and developed through active repeated guided practice. Problem based } \\
\text { learning based on constructivism helps develop this skills. }\end{array}$ & 2 \\
\hline Kuiper and Pesut [17] & $\begin{array}{l}\text { Objective: To explore the impact of self-regulated learning theory on } \\
\text { reflective practice in nursing, and to advance the idea that both } \\
\text { cognitive and metacognitive skills support the development of } \\
\text { clinical reasoning skills. } \\
\text { Integrative review of published literature in social science, educational } \\
\text { psychology, nursing education, and professional education }\end{array}$ & $\begin{array}{l}\text { Level of education: undergraduate, graduate, postgraduate } \\
\text { Learner profession: nursing } \\
\text { Findings: Reflective clinical reasoning in nursing practice depends on the } \\
\text { development of both cognitive and metacognitive skill acquisition. } \\
\text { This skill acquisition is best accomplished through teaching-learning attention } \\
\text { to self-regulation learning theory. }\end{array}$ & 4 \\
\hline $\begin{array}{l}\text { Rushmer, Kelly, } \\
\text { Lough, Wilkinson } \\
\text { and Davies [18] }\end{array}$ & $\begin{array}{l}\text { Systematic literature review of contextual factors that play a } \\
\text { key role in providing a facilitative context for a Learning Practice } \\
\text { or manifest themselves as barriers to any Practice's attempts to } \\
\text { develop a learning culture. }\end{array}$ & $\begin{array}{l}\text { Level of education: undergraduate, graduate, postgraduate } \\
\text { Learner profession: healthcare } \\
\text { Findings: Core contextual conditions are identified the requirement for strong } \\
\text { and visionary leadership; the involvement and empowerment of staff; } \\
\text { and setting-aside of times and places for learning and reflection. }\end{array}$ & 2 \\
\hline $\begin{array}{l}\text { Crowe and } \\
\text { O'Malley [19] }\end{array}$ & $\begin{array}{l}\text { Objective: Literature review conducted to establish what was already } \\
\text { known about critical reflection in the nursing literature and what work } \\
\text { had been done on using a critical social theory framework as the basis } \\
\text { for critical reflection. }\end{array}$ & $\begin{array}{l}\text { Level of education: undergraduate, graduate, postgraduate } \\
\text { Learner profession: nursing, mental health nursing } \\
\text { Findings: There were } 490 \text { articles related to "nursing" and "critical thinking"; } \\
34 \text { articles related to "nursing" and "critical reflection"; } 23 \text { articles related to } \\
\text { "nursing" and "critical social theory"; } 15 \text { articles related to "mental health } \\
\text { nursing" and "critical thinking"; and two articles related to "mental health } \\
\text { nursing" and "critical reflection" } \\
\text { Students were facilitated to deconstruct concepts and knowledge integral to } \\
\text { their own practice. In the reconstructive phase, students implement a change } \\
\text { project in clinical practice, supported by a mentor }\end{array}$ & 5 \\
\hline
\end{tabular}


Table 1. Cont

\begin{tabular}{|c|c|c|c|}
\hline Authors & Objective and Methods & Summary of Findings & AMSTAR Score \\
\hline Epp [20] & $\begin{array}{l}\text { Objective: to ascertain the evidence for the use of reflective journaling as } \\
\text { a tool to promote the pedagogical strategy of reflection for the purpose } \\
\text { of learning from practice for practice in undergraduate nursing } \\
\text { education. Systematic literature from } 1992 \text { to } 2006 \text {. Nine studies met } \\
\text { the inclusion criteria. }\end{array}$ & $\begin{array}{l}\text { Level of education: undergraduate } \\
\text { Learner profession: nursing, physiotherapy } \\
\text { Findings: Educators struggle to incorporate reflective processes into education; } \\
\text { research provided rationale and support for engaging undergraduate students } \\
\text { in the reflective process. Researchers found reasonable levels of reflection in } \\
\text { undergraduate students' journaling and educators reported students' learning } \\
\text { as a result of reflective journaling. Writing reflectively improved over time; } \\
\text { a learned skill also dependent on a good facilitator and trust. }\end{array}$ & 5 \\
\hline $\begin{array}{l}\text { Buckley, Coleman, } \\
\text { Davison, Khan, } \\
\text { Zamora, Malick, } \\
\text { Morley, Pollard, } \\
\text { Ashcroft, Popovic } \\
\text { and Sayers [21] }\end{array}$ & $\begin{array}{l}\text { Objective: A systematic review to assess use of } \\
\text { portfolios in undergraduate education. } \\
\text { Sixty-nine studies included (medicine, nursing, } \\
\text { allied health professionals). }\end{array}$ & $\begin{array}{l}\text { Level of education: undergraduate } \\
\text { Learner profession: medicine, nursing, allied health professionals } \\
\text { Findings: Portfolios were used mainly in the clinical setting, completion was } \\
\text { mostly compulsory, reflection required and assessment (either formative, } \\
\text { summative or a combination of both) the norm. Nine of the studies reported } \\
\text { direct measurement of changes in student skills or attitudes and one study } \\
\text { reported a change in student behaviour. The main effects of portfolio use } \\
\text { identified by the included studies were: improvement in student knowledge } \\
\text { and understanding, greater self-awareness and encouragement of reflection } \\
\text { and the ability to learn independently, greater self-awareness and } \\
\text { engagement in reflection. }\end{array}$ & 12 \\
\hline $\begin{array}{l}\text { Mann, Gordon and } \\
\text { MacLeod [22] }\end{array}$ & $\begin{array}{l}\text { Objective: systematic review of the research literature } \\
\text { in the area of reflection and reflective learning in health } \\
\text { professional education and practice. } \\
\text { Twenty-nine studies identified }\end{array}$ & $\begin{array}{l}\text { Level of education: undergraduate, graduate or postgraduate } \\
\text { Learner profession: medicine, nursing, other health professions } \\
\text { Findings: Eight studies explored reflective practice in practicing professionals; } \\
\text { six were in medicine, and two in nursing. Reflection was a part of practice in all } \\
\text { eight reports. Eight studies explored reflection in medical and health } \\
\text { professions students, relating it to learning, professional identity development, } \\
\text { and critical thinking } \\
\text { Nine studies addressed whether reflective practice can be assessed. } \\
\text { In several of the studies, relationships with other variables were explored, } \\
\text { as a means of validating the instruments used and assessments made. } \\
\text { Four studies addressed the development of reflective thinking. Twelve studies } \\
\text { addressed the contextual influences which hinder or enable the development of } \\
\text { reflection and reflective capability. }\end{array}$ & 7 \\
\hline
\end{tabular}


Table 1. Cont

\begin{tabular}{|c|c|c|c|}
\hline Authors & Objective and Methods & Summary of Findings & AMSTAR Score \\
\hline $\begin{array}{l}\text { Lethbridge, } \\
\text { Andrusyszyn, Iwasiw, } \\
\text { Laschinger and } \\
\text { Fernando [23] }\end{array}$ & $\begin{array}{l}\text { Objective: integrative literature review; three concepts are examined and } \\
\text { linked-structural empowerment (as conceptualized by Kanter), } \\
\text { psychological empowerment (as described by Spreitzer), } \\
\text { and reflective thinking (as characterized by Mezirow)-and a } \\
\text { theoretical model for testing is proposed. } \\
\text { Three dominant theories identified }\end{array}$ & $\begin{array}{l}\text { Level of education: undergraduate or postgraduate } \\
\text { Learner profession: nursing } \\
\text { Findings: Students' perceptions of empowerment in the nursing profession } \\
\text { begin to form during their studies, and they are introduced to the process of } \\
\text { reflective thinking. All three are required for learning and nursing practice. } \\
\text { By preparing students to be empowered, reflective professionals, it is proposed } \\
\text { that they will be more effective in their academic and future practice work. }\end{array}$ & 5 \\
\hline $\begin{array}{l}\text { Chaffey, de Leeuw } \\
\text { and Finnigan [24] }\end{array}$ & $\begin{array}{l}\text { Systematic review of the literature was undertaken using defined } \\
\text { databases and the search terms "medical students", "medical } \\
\text { education", "reflection", "reflectFNx01" and "medicine". The search was } \\
\text { limited to peer-reviewed published material in English and between the } \\
\text { years } 2001 \text { and 2011, and included research, reviews and opinion pieces. }\end{array}$ & $\begin{array}{l}\text { Level of education: undergraduate, graduate or postgraduate } \\
\text { Learner profession: medicine } \\
\text { Findings: Thirty-six relevant articles identifying enhancing factors and barriers } \\
\text { to effectively teaching reflective practice within medical curricula, relating to: } \\
\text { The breadth of the meaning of reflection; facilitating reflection by medical } \\
\text { educators; using written or web-based portfolios to facilitate reflection; and } \\
\text { assessing the reflective work of students. }\end{array}$ & 6 \\
\hline $\begin{array}{l}\text { Norrie, Hammond, } \\
\text { D'Avray, Collington } \\
\text { and Fook [25] }\end{array}$ & $\begin{array}{l}\text { Objective: What types of literature were found? What were the } \\
\text { justifications for and criticisms of teaching reflection in the different } \\
\text { professions? } \\
\text { What were the learning contexts and the pedagogical approaches for } \\
\text { teaching and assessing reflection in the different professions? } \\
\text { Fifty-two studies included in review after systematic literature search }\end{array}$ & $\begin{array}{l}\text { Level of education: undergraduate, graduate or postgraduate } \\
\text { Learner profession: nursing, midwifery, physiotherapists, social work, } \\
\text { multi/interprofessional } \\
\text { Findings: the study identified and categorised literature available on teaching } \\
\text { reflective practice in health and social care and compared this with what was } \\
\text { available interprofessionally and multiprofessionally. Identified common } \\
\text { reflective teaching methods and assessment methods. }\end{array}$ & 7 \\
\hline $\begin{array}{l}\text { Prasko, Mozny, } \\
\text { Novotny, Slepecky } \\
\text { and Vyskocilova [26] }\end{array}$ & $\begin{array}{l}\text { Objective: To review aspects related to supervision in cognitive } \\
\text { behavioural therapy and self-reflection in the literature. } \\
\text { A literature review was performed using the PubMed, SciVerse Scopus, } \\
\text { and Web of Science databases; additional references were found through } \\
\text { bibliography reviews of relevant articles published prior to July 2011. }\end{array}$ & $\begin{array}{l}\text { Level of education: undergraduate, graduate or postgraduate } \\
\text { Learner profession: Therapists } \\
\text { Findings: Self-reflection in therapy is a continuous process which is essential for } \\
\text { the establishment of a therapeutic relationship, the professional growth of the } \\
\text { therapist, and the ongoing development of therapeutic skills. The ability to } \\
\text { self-reflect increases the ability to perceive other people's inner emotions, } \\
\text { kindles altruism, and increases attunement to subtle signals indicating what } \\
\text { others need or want. Self-reflection may be practised by the therapists } \\
\text { themselves using traditional cognitive behavioural therapy techniques, } \\
\text { or it may be learned in the course of supervision. }\end{array}$ & 4 \\
\hline
\end{tabular}


Table 1. Cont.

\begin{tabular}{|c|c|c|c|}
\hline Authors & Objective and Methods & Summary of Findings & AMSTAR Score \\
\hline $\begin{array}{l}\text { Jayatilleke and } \\
\text { Mackie [27] }\end{array}$ & $\begin{array}{l}\text { Objective: To investigate the reported contribution, of reflection by } \\
\text { public health workers as part of their professional practice. } \\
\text { A systematic review of the literature to identify reflective experience } \\
\text { in public health or health education. Thirteen papers met the inclusion } \\
\text { criteria and were reviewed }\end{array}$ & $\begin{array}{l}\text { Level of education: undergraduate, graduate or postgraduate } \\
\text { Learner profession: nursing, allied health professionals } \\
\text { Findings: Limited but growing evidence to suggest reflection improves } \\
\text { practice in disciplines allied to public health. No specific models are } \\
\text { currently recommended or widely used in public health. }\end{array}$ & 5 \\
\hline Chen and Forbes [28] & $\begin{array}{l}\text { Objective: to find the emotional effects of reflective writing interventions } \\
\text { on medical and healthcare students } \\
\text { Systematic literature Review with } 8 \text { final publications analysed }\end{array}$ & $\begin{array}{l}\text { Level of education: undergraduate or graduate } \\
\text { Learner profession: Medical students, pharmacy students } \\
\text { Findings: The outcomes measured included impact of reflective writing } \\
\text { exercises on student wellness, aptitude, and/or clinical skills. Of these studies, } \\
\text { a significant change in student empathy was observed in } 100 \% \text { of the studies, } \\
\text { demonstrating a significant change in outcomes. }\end{array}$ & 6 \\
\hline $\begin{array}{l}\text { Nguyen, Fernandez, } \\
\text { Karsenti and } \\
\text { Charlin [29] }\end{array}$ & $\begin{array}{l}\text { Objective: to identify, explore and analyse the most influential } \\
\text { conceptualisations of reflection, and to develop a new theory-informed } \\
\text { and unified definition and model of reflection. } \\
\text { Systematic review to identify the } 15 \text { most cited authors in papers on } \\
\text { reflection published during the period from } 2008 \text { to } 2012 \text { ( } 74 \text { papers) } \\
\text { An exploratory thematic analysis was carried out and identified seven } \\
\text { initial categories. Categories were clustered and reworded to develop an } \\
\text { integrative definition and model of reflection, which feature core } \\
\text { components that define reflection and extrinsic elements that influence } \\
\text { instances of reflection. }\end{array}$ & $\begin{array}{l}\text { Level of education: undergraduate, graduate or postgraduate } \\
\text { Learner profession: Medical Education } \\
\text { Five core components of reflection and two extrinsic elements were identified: } \\
\text { Reflection is defined as the process of engaging the self in attentive, critical, } \\
\text { exploratory and iterative interactions with one's thoughts and actions, } \\
\text { and their underlying conceptual frame, with a view to changing them and a } \\
\text { view on the change itself. Extrinsic elements: are the trigger of reflection } \\
\text { and the context of reflection. }\end{array}$ & 7 \\
\hline $\begin{array}{l}\text { McGillivray, } \\
\text { Gurtman, Boganin } \\
\text { and Sheen [30] }\end{array}$ & $\begin{array}{l}\text { Objective: To investigate the effect of self-practice and self-reflection } \\
\text { on therapist skills development. } \\
\text { Systematic Review of English studies that investigated the effect of } \\
\text { self-practice and/or self-reflection on therapist skill development. } \\
\text { No restriction on sample sizes, design of studies, dates of publication, } \\
\text { or peer-reviewed papers. }\end{array}$ & $\begin{array}{l}\text { Level of education: undergraduate, graduate or postgraduate } \\
\text { Learner profession: Therapists } \\
\text { Findings: Ten studies included in review. The meta-synthesis revealed } \\
\text { inconsistencies between the qualitative and quantitative literature and a gap } \\
\text { in relation to declarative knowledge. Six themes identified: improved technical } \\
\text { skills, increased self-awareness, increased interpersonal, perceptual, } \\
\text { and relational skills, appreciation for the limitations and value of the } \\
\text { therapeutic model, increased empathy for clients, understanding of } \\
\text { discomfort associated with self-disclosure. }\end{array}$ & 11 \\
\hline
\end{tabular}


Table 1. Cont.

\begin{tabular}{|c|c|c|c|}
\hline Authors & Objective and Methods & Summary of Findings & AMSTAR Score \\
\hline $\begin{array}{l}\text { Miraglia and } \\
\text { Asselin [31] }\end{array}$ & $\begin{array}{l}\text { Systematic review of the literature. } 25 \text { English studies that explored } \\
\text { reflective education strategies in pot license nurses in a clinical setting. }\end{array}$ & $\begin{array}{l}\text { Level of education: postgraduate } \\
\text { Learner profession: Nursing (nursing professional development) } \\
\text { Findings: Two themes for reflection as educational strategy: meeting a specific } \\
\text { clinical practice goal and teaching nurses how to reflect to enhance individual } \\
\text { reflective practice. Three themes emerged regarding the way in which reflection } \\
\text { was used as an educational strategy: reflection nested into multifaceted } \\
\text { educational programs, individual- versus group-facilitated reflection, and } \\
\text { structured versus unstructured reflection. Overall, reflection is noted with an } \\
\text { increase in knowledge, changed attitudes, values, beliefs, and assumptions of } \\
\text { individual participants and the potential for group reflective strategies to make } \\
\text { a meaningful impact at the organizational level. }\end{array}$ & 9 \\
\hline $\begin{array}{l}\mathrm{Ng} \text {, Kinsella, Friesen } \\
\text { and Hodges [32] }\end{array}$ & $\begin{array}{l}\text { Non-systematic search of the literature with view to capture dominant } \\
\text { reflective applications and relate them to theoretical approaches }\end{array}$ & $\begin{array}{l}\text { Level of education: undergraduate, graduate or postgraduate } \\
\text { Learner profession: Medical Education } \\
\text { Findings: Theoretical orientations of reflection are: reflection as epistemology of } \\
\text { practice and reflection as critical social inquiry. Three prevalent trends in the } \\
\text { application of reflection: utilitarian applications of reflection; focus on the self as } \\
\text { the object of reflection, and reflection and assessment. Trends align with } \\
\text { dominant epistemological positions in medicine (e.g., evidence based medicine), } \\
\text { but not with those that underpin reflection. }\end{array}$ & 4 \\
\hline $\begin{array}{l}\text { Tsingos, } \\
\text { Bosnic-Anticevich, } \\
\text { Lonie and Smith } \\
{[33,34]}\end{array}$ & $\begin{array}{l}\text { Objective. To research the literature and examine assessment strategies } \\
\text { used in health education that measure reflection levels and to identify } \\
\text { assessment strategies for use in pharmacy education. } \\
\text { A systematic review approach of studies from the last } 20 \text { years }\end{array}$ & $\begin{array}{l}\text { Level of education: undergraduate, graduate, postgraduate } \\
\text { Learner profession: medicine, nursing, allied healthcare professionals } \\
\text { Findings: The literature search identified assessment strategies and rubrics used } \\
\text { in health education for assessing levels of reflection. Reflective techniques used: } \\
\text { reflective journal, portfolio, log, blog, questionnaire, video and diary. } \\
\text { There is a significant gap in the literature regarding reflective rubric use } \\
\text { in pharmacy education. }\end{array}$ & 9 \\
\hline $\begin{array}{l}\text { Van Roy, Vanheule } \\
\text { and Inslegers [35] }\end{array}$ & $\begin{array}{l}\text { Objective: Systematic review looking at Balint groups. } \\
\text { Ninety-four articles included; } 35 \text { are empirical studies adopting } \\
\text { a qualitative, quantitative or mixed methodology. }\end{array}$ & $\begin{array}{l}\text { Level of education: undergraduate, graduate, postgraduate } \\
\text { Learner profession: medicine, nursing, allied healthcare professionals } \\
\text { Findings: The research topics that emerged include outcome, characteristics } \\
\text { of Balint group participants, themes addressed in Balint groups, Balint group } \\
\text { processes, and leadership and Balint group evaluations. }\end{array}$ & 9 \\
\hline
\end{tabular}




\subsection{Methodological Quality}

The average AMSTAT score was 6 (range 2-12). This value indicates an average of six Yes answers to all twelve items, indicating moderate overall quality. Low scores (poor quality) stem from the items regarding publication status as an inclusion criterion, the listing of excluded studies, the inclusion of study characteristics and quality assessment. Most of these studies were qualitative reviews; thus, statistical analysis could not be assessed.

\subsection{Which Models and Definitions of Reflection and Reflective Practice Are Used?}

Nguyen, Fernandez, Karsenti, and Charlin [29] developed a conceptual model for reflection that identified five core components of reflective practice categorised with respect to content, process, or both. These five components constitute what reflection actually is: thoughts and actions are content related; the attentive, critical, exploratory and iterative process is process related; and the underlying conceptual frame and the view on change and the self are categorised are content- and process-related. Their analysis is summarised in this eloquent definition:

Reflection is the process of engaging the self in attentive, critical, exploratory, and iterative interactions with one's thoughts and actions, and their underlying conceptual frame, with a view to changing them and with a view on the change itself [29].

This definition should consider the trigger and context of reflection as extrinsic elements to complete the reflection model. Examples of trigger and context include experience and timing. This broad but accurate definition encompasses elements from multiple definitions from theorists of reflective practice, such as John Dewey [52], Donald Schön [2,7], Chris Argyris [53,54], Boyd and Fales [55], Kolb [56], David Boud [57], and Jack Mezirow [58]. The definition includes iterative elements from Schön [2,7] (1. knowing-in-action; 2. Surprise; 3. reflection-in-action; 4. Experimentation; 5. reflection-on-action) and Boud, Keogh, and Walker [57] (1. returning to experience; 2 . attending to feelings; 3 . re-evaluation of experience; 4 . outcome/resolution). The vertical dimension of reflection with different levels of reflection on experience is maintained: surface levels are more descriptive and less analytical than deeper levels of analysis and critical synthesis [22,52,58].

An important element of this definition is its attention to self- and critical reflection and their subtle, but distinct, differences. Williams [16] describes each type of reflection succinctly:

Professional education scholars concur that specialized knowledge is clearly essential for professional practice; however, they also suggest that self-consciousness (reflection) and continual self-critique (critical reflection) are crucial to continued competence. [ ... ] Reflection is an examination of the content or description of an issue or problem and involves checking on the problem solving strategies that are being used-[ ... ] an examination of 'What?' and 'How?'. [ . . . Critical reflection is stimulated by perceived discrepancies between a learner's beliefs, values, or assumptions and new information, knowledge, understanding, or insight, [ ... ] a dialogue journal which describes the learner's self-analysis and the educator's or fellow learner's responses is one strategy for stimulating critical reflection.

An epistemological paradox regarding reflection appears to exist. The two main theoretical orientations of reflection, according to the critical review by $\mathrm{Ng}$, Kinsella, Friesen, and Hodges [32], are reflection as epistemology of practice and reflection as critical social inquiry. Historically, these underpinnings associate reflection with plurality and a form of artistry that Schön [2] initially envisaged and described. The paradox becomes apparent when a critical assessment of the literature reveals three prevalent trends in the application of reflection in medical education: utilitarian applications of reflection, the focus on the self as the object of reflection, and reflection and assessment [32]. When these trends are problematized, reflection appears to be influenced more by a reductionist approach aligned with dominant epistemological positions in medicine, such as evidence-based medicine, than by the historically critical (artistic) philosophical underpinnings. In the pursuit of the measurement of learning outcomes, the quantification of achievement and the management of educational objectives, learning is technically rationalised, and possibly removed, from the artistry that Schön [2] and other influential 
writers proposed $[59,60]$. This epistemological incongruence is prevalent in the reflection literature analysed in the current study, and highlights the value of umbrella reviews to reveal such diversity.

\subsection{How Does Empirical Research Depict Reflective Practice in Healthcare Education (Design and Evaluation} of Education Interventions)?

Numerous studies have examined the design and evaluation of education interventions with respect to reflection. Norrie, Hammond, D'Avray, Collington, and Fook [25] conducted a systematic review examining reflection in pedagogical approaches in different healthcare professions. They categorised the use of reflective techniques, first, into summative methods, which include portfolios (paper or electronic), reflective diaries/autobiographical stories (paper or electronic), critical incident reports/essays and seminar presentations. These methods are followed by formative methods, such as class exercises, facilitation (the use of models and frameworks), and self-reflection guided by critical friends, supervisors, mentors, preceptors or peer observation. Similarly, the systematic review by Buckley, Coleman, Davison, Khan, Zamora, Malick, Morley, Pollard, Ashcroft, Popovic, and Sayers [21] examined the prevalence of portfolio use in healthcare education and the educational effects. Meanwhile, Tsingos, Bosnic-Anticevich, Lonie, and Smith [33] summarised multiple reflective techniques for teaching and learning, providing an exhaustive account of the use of reflective journals, portfolios, logs, blogs, questionnaires, videos, and diaries.

Moving from description to schematisation, Miraglia and Asselin [31] investigated reflection in the context of nursing professional development. Analysing seventeen studies, they identified two themes for reflection as an educational strategy. One theme is meeting a specific clinical practice goal, and the other is teaching nurses how to reflect to enhance individual reflective practice. Examples include a mandatory training programme that included a reflective strategy to enhance healthcare providers' ability to meet patients' mental health needs [61] or a work-based initiative that included reflective diaries to enhance therapeutic communication with service users in acute mental health settings [62]. Those authors also described the process of teaching nurses how to reflect to promote reflective practice, insight and reflective thinking; how to promote reflective practice through group-guided reflection; how to gain deeper levels of reflection on clinical practice; and how to explore reflective journaling [31]. Reflective journaling and reflective writing have also been frequent topics of enquiry in other reviews. Epp [20] found that once students are motivated to participate in classes with reflective journaling, their learning increases as a result of reflective journaling, according to educators. Writing reflectively improves over time, and this form of writing is considered a learned skill that is dependent on a good facilitator and trust.

Miraglia and Asselin [31] then proceeded to propose another categorisation of the use of reflection as an educational strategy: reflection nested into multifaceted educational programmes, individual versus group-facilitated reflection, and structured versus unstructured reflection. This categorisation can be combined with the themes described in the previous paragraph by the same authors [31], and various reflection strategies can be produced. For instance, when reflection is nested into multifaceted educational programmes, information that is relevant to the clinical practice setting and educational goals of the project are presented to participants and paired with a reflective educational strategy, stimulating tacit knowledge development and experiential learning. Dialogues with reflective narratives (written or verbal, individual, or group) relevant to a clinical situation are also a technique frequently reported and related to the second theme. The use of facilitators to guide, direct and expand the reflective exploration of shared narratives in a group setting is an important aspect of this theme [63]. Balint groups are another example of group discussion with reflective content. In their systematic review, Van Roy, Vanheule, and Inslegers [35] examined the relationship between reflective practice and outcomes for healthcare professionals. Reflective participation increased psychosocial self-efficacy, possibly decreased burnout/dissatisfaction and improved participants' attitudes, but did not increase their knowledge. 
In the final theme by Miraglia and Asselin [31], the authors discussed structured versus unstructured reflection. Structured reflection refers to reflection-guided question cues that provide guidance and structure for the exercise. Typically non-prescriptive, unstructured reflection uses participants' thoughts triggered by a certain event (usually a clinical situation or scenario). Examples of reflection-guided question cues for observing include the following: What just happened? What were you thinking when ... ? Did you notice that ... ? What surprised us in that case? How does it make you feel? Question triggers for processing include the following: Are we doing this the right way? Are there alternatives? Is this applicable in our setting? What does this mean? Why does it make you feel this way? What are the consequences of you feeling like this? Are we the right people to address this? Finally, questions for future action include the following: What do we need (e.g., resources, knowledge, skills) to resolve this problem? What will we do differently next time? What are the barriers to ... ? What can facilitate ... ? [64].

The aforementioned reflective techniques highlight an increase in knowledge and clinical skills and are generally considered to be effective learning strategies. Additionally, on a more abstract level, two additional themes are recognised as beneficial outcomes of reflective strategies. First, reflection appears to have an effect on changing the attitudes, values, beliefs, and assumptions of individual participants, and second, it provides the grounds for a meaningful impact at the organisational level [29-33,35]. An interesting study from the psychotherapy field provides insight into the potential benefits of reflective techniques [30]. This meta-synthesis review included ten studies, and, despite inconsistencies between the qualitative and quantitative literature and a gap in relation to declarative knowledge, the review identified six distinct themes: improved technical skills; increased self-awareness; increased interpersonal, perceptual and relational skills; appreciation for the limitations and value of the therapeutic model; increased empathy for clients; and understanding of the discomfort associated with self-disclosure. The authors also noted themes similar to those in Miraglia and Asselin [31], such as written reflection, collated and shared reflection and group/verbal reflection.

In addition to the design of reflective education strategies, examining how reflection can be assessed is also important. In their review, Mann, Gordon, and MacLeod [22] identified nine studies that addressed this issue. A common practice was to compare reflective thinking scales to other scales not only for validation but also for examination of how reflective thinking is associated with learning and understanding. For example, Sobral [65] supported the theoretical stance that reflection and deep learning are positively related by correlating his 14-item Reflection-in-Learning Scale with the Course Valuing Inventory and the Approaches to Study Inventory. Another group developed a highly reliable reflective thinking scale that has components of deliberate induction, deliberate deduction, testing and synthesising, openness for reflection, and meta-reasoning, all strongly correlated with a doctor's expertise [66]. However, Mann, Gordon, and MacLeod [22] eventually concluded as follows:

Reflection can be assessed and different levels of reflection discerned [ . . but] students do not have the same opportunities as professionals do for reflective practice in authentic settings and therefore some questions remain regarding whether what is being measured (e.g., text) is a valid indicator of reflective activity, when one considers the influences of context and culture.

Overall, the studies analysed in the current review provide a fair description of the design of reflective techniques and their related benefits for self- and critical reflection. In addition, assessment as a topic of research has less frequently been examined than design.

\subsection{What Are the Future Directions of Reflective Research and Practice in Healthcare Education?}

The described paradoxes of reflection in healthcare education research continue to present problems for researchers, necessitating further studies regarding the theory, design, and assessment of reflection. Mann, Gordon, and MacLeod [22] insightfully posed the following eight questions that they believe need answering in future studies because they are currently not fully addressed: Does reflection enhance learning? Does reflection improve self-understanding? Is reflection most effective when shared? What is the role of "reflection-in-action"? Does reflection enhance self-assessment? 
Does reflection alter clinical behaviour? Does reflection improve patient care? Can reflective practice be taught and learned?

Reviews attempting to answer some of these questions find evidence that reflective thinking is related to deep learning and understanding and, when performed in a structured manner, can be taught, learned, replicated, and measured [16-35]. However, the retrospective nature of examining reflection through writing journals, blogs, vlogs, portfolios, or other methods does not allow complete assessment of reflection-in-action, which is one of Schön's [2,7] primary theoretical contributions to reflection and the purposes of reflection. The entire discussion concerning evidence in the reflection literature altogether justifies the title of the review by $\mathrm{Ng}$, Kinsella, Friesen, and Hodges [32], Reclaiming a theoretical orientation to reflection in medical education, as discussed above in the reflection models and definition section.

\section{Discussion and Conclusions}

This work is the first umbrella review to address reflection in healthcare education. We reviewed twenty reviews that satisfied the inclusion criteria; these included studies from the medicine, nursing, and allied health professions (physiotherapists, occupational therapists, pharmacists, therapists, social workers, and psychologists). The educational levels of participants ranged from undergraduate education to continuing professional development, and the average quality assessment was moderate according to the AMSTAR scale. The current review examined three questions of models and definitions currently used for reflection in healthcare education, reflective techniques for educational interventions and assessment and future challenges.

The results indicated that theoretical models originate from an epistemology of practice as envisaged by Dewey [52] and Schön [2], including elements of critical reflection. A useful definition has been provided by Nguyen, Fernandez, Karsenti, and Charlin [29]. A theoretical paradox is observed between the theoretical underpinnings of reflection and its current research or application, including attempts to approach it from a utilitarian evidenced-based perspective. Although not mutually exclusive, these approaches likely indicate a departure from the original theory. Despite this contradiction, reflection is having a continuous impact on education, design, and assessment. Many reflective techniques used in healthcare education have been associated with deep learning, understanding, attitudes, beliefs, and satisfaction, and reflection appears to be positively associated with various learning outcomes. The assessment of reflective learning remains an issue under investigation.

Researchers and practitioners face various challenges in reflection and healthcare education. Researchers must address questions of theory and measurement and likely need to propose methods of designing reflective techniques that can also be assessed. Practitioners must also address issues of incorporating reflection into their daily practice and ensuring that the assessment of reflection is performed reliably. Although reflection has been correlated with many positive outcomes, a general observation is that assessment is extremely heterogeneous with a certain ambiguity in what is actually assessed. One of the many cautions is the avoidance as much as possible of a utilitarian approach.

The current study has limitations. Each research field has an epistemological premise, and the challenge in reflection research is maintaining a balance between a positivistic approach, which is assumed in the evidence-based approach of systematic reviews, and the strongly interpretive nature of reflection. Attempts have been made to address this issue through a critical and levelled approach to the findings and the use of the AMSTAR scale. Other limitations stem from methodological biases, such as the individual design or reporting of biases of the included reviews, heterogeneity in the quality of the reviews (more recent reviews are scored higher on the AMSTAR scale) and the lack of quantitative synthesis. Even with these limitations, however, the current review shows that reflection is having an ongoing impact on healthcare education. The abundance of evidence available has given rise to new challenges and has highlighted ongoing problematic areas in theory and application for both researchers and practitioners. 
Conflicts of Interest: The authors declare no conflict of interest.

\section{Abbreviations}

The following abbreviations are used in this manuscript:

AMSTAR Assessing the Methodological Quality of Systematic Reviews

\section{References}

1. Glazer, N. The schools of the minor professions. Minerva 1974, 12, 346-364. [CrossRef]

2. Schön, D.A. The Reflective Practitioner: How Professionals Think in Action; Basic Books: New York, NY, USA, 1983.

3. Frenk, J.; Chen, L.; Bhutta, Z.A.; Cohen, J.; Crisp, N.; Evans, T.; Fineberg, H.; Garcia, P.; Ke, Y.; Kelley, P.; et al. Health professionals for a new century: Transforming education to strengthen health systems in an interdependent world. Lancet 2010, 376, 1923-1958. [CrossRef]

4. Noar, S.M.; Zimmerman, R.S. Health behavior theory and cumulative knowledge regarding health behaviors: Are we moving in the right direction? Health Educ. Res. 2005, 20, 275-290. [CrossRef] [PubMed]

5. Zibrowski, E.M.; Weston, W.W.; Goldszmidt, M.A. "I don't have time": Issues of fragmentation, prioritisation and motivation for education scholarship among medical faculty. Med. Educ. 2008, 42, 872-878. [CrossRef] [PubMed]

6. Kauffman, D.M.; Mann, K.V. Teaching and learning in medical education: How theory can inform practice. In Understanding Medical Education, 2nd ed.; Swanwick, T., Ed.; Wiley: Chichester, UK, 2014; pp. 16-36.

7. Schön, D.A. Educating the Reflective Practitioner: Toward a New Design for Teaching and Learning in the Professions, 1st ed.; Jossey-Bass: San Francisco, CA, USA, 1987.

8. Onyura, B.; Baker, L.; Cameron, B.; Friesen, F.; Leslie, K. Evidence for curricular and instructional design approaches in undergraduate medical education: An umbrella review. Med. Teach. 2016, 38, 150-161. [CrossRef] [PubMed]

9. Tsagris, M.; Fragkos, K.C. Umbrella reviews, overviews of reviews, and meta-epidemiologic studies: Similarities and differences. In Umbrella Reviews: Evidence Synthesis with Overviews of Reviews and Meta-Epidemiologic Studies; Biondi-Zoccai, G., Ed.; Springer International Publishing: Cham, Switzerland, 2016; pp. 43-54.

10. Aromataris, E.; Fernandez, R.; Godfrey, C.M.; Holly, C.; Khalil, H.; Tungpunkom, P. Summarizing systematic reviews: Methodological development, conduct and reporting of an umbrella review approach. Int. J. Evid. Based Healthc. 2015, 13, 132-140. [CrossRef] [PubMed]

11. Shea, B.J.; Bouter, L.M.; Peterson, J.; Boers, M.; Andersson, N.; Ortiz, Z.; Ramsay, T.; Bai, A.; Shukla, V.K.; Grimshaw, J.M. External validation of a measurement tool to assess systematic reviews (amstar). PLoS ONE 2007, 2, e1350. [CrossRef] [PubMed]

12. Shea, B.J.; Grimshaw, J.M.; Wells, G.A.; Boers, M.; Andersson, N.; Hamel, C.; Porter, A.C.; Tugwell, P.; Moher, D.; Bouter, L.M. Development of amstar: A measurement tool to assess the methodological quality of systematic reviews. BMC Med. Res. Methodol. 2007, 7, 1-7. [CrossRef] [PubMed]

13. Edgley, A.; Stickley, T.; Timmons, S.; Meal, A. Critical realist review: Exploring the real, beyond the empirical. J. Furth. High. Educ. 2016, 40, 316-330. [CrossRef]

14. Clegg, S. Evidence-based practice in educational research: A critical realist critique of systematic review. Br. J. Sociol. Educ. 2005, 26, 415-428. [CrossRef]

15. Petitmengin, C. Describing one's subjective experience in the second person: An interview method for the science of consciousness. Phenomenol. Cogn. Sci. 2006, 5, 229-269. [CrossRef]

16. Williams, B. Developing critical reflection for professional practice through problem-based learning. J. Adv. Nurs. 2001, 34, 27-34. [CrossRef] [PubMed]

17. Kuiper, R.A.; Pesut, D.J. Promoting cognitive and metacognitive reflective reasoning skills in nursing practice: Self-regulated learning theory. J. Adv. Nurs. 2004, 45, 381-391. [CrossRef] [PubMed]

18. Rushmer, R.; Kelly, D.; Lough, M.; Wilkinson, J.E.; Davies, H.T. Introducing the learning practice-III. Leadership, empowerment, protected time and reflective practice as core contextual conditions. J. Eval. Clin. Pract. 2004, 10, 399-405. [CrossRef] [PubMed] 
19. Crowe, M.T.; O'Malley, J. Teaching critical reflection skills for advanced mental health nursing practice: A deconstructive-reconstructive approach. J. Adv. Nurs. 2006, 56, 79-87. [CrossRef] [PubMed]

20. Epp, S. The value of reflective journaling in undergraduate nursing education: A literature review. Int. J. Nurs. Stud. 2008, 45, 1379-1388. [CrossRef] [PubMed]

21. Buckley, S.; Coleman, J.; Davison, I.; Khan, K.S.; Zamora, J.; Malick, S.; Morley, D.; Pollard, D.; Ashcroft, T.; Popovic, C.; et al. The educational effects of portfolios on undergraduate student learning: A best evidence medical education (beme) systematic review. Beme guide No. 11. Med. Teach. 2009, 31, 282-298. [CrossRef] [PubMed]

22. Mann, K.; Gordon, J.; MacLeod, A. Reflection and reflective practice in health professions education: A systematic review. Adv. Health Sci. Educ. Theory Pract. 2009, 14, 595-621. [CrossRef] [PubMed]

23. Lethbridge, K.; Andrusyszyn, M.A.; Iwasiw, C.; Laschinger, H.K.; Fernando, R. Structural and psychological empowerment and reflective thinking: Is there a link? J. Nurs. Educ. 2011, 50, 636-645. [CrossRef] [PubMed]

24. Chaffey, L.J.; de Leeuw, E.J.; Finnigan, G.A. Facilitating students' reflective practice in a medical course: Literature review. Educ. Health (Abingdon) 2012, 25, 198-203. [CrossRef] [PubMed]

25. Norrie, C.; Hammond, J.; D'Avray, L.; Collington, V.; Fook, J. Doing it differently? A review of literature on teaching reflective practice across health and social care professions. Reflect. Pract. 2012, 13, 565-578. [CrossRef]

26. Prasko, J.; Mozny, P.; Novotny, M.; Slepecky, M.; Vyskocilova, J. Self-reflection in cognitive behavioural therapy and supervision. Biomed. Pap. Med. Fac. Univ. Palacky Olomouc Czech. Repub. 2012, 156, 377-384. [CrossRef] [PubMed]

27. Jayatilleke, N.; Mackie, A. Reflection as part of continuous professional development for public health professionals: A literature review. J. Public Health (Oxf.) 2013, 35, 308-312. [CrossRef] [PubMed]

28. Chen, I.; Forbes, C. Reflective writing and its impact on empathy in medical education: Systematic review. J. Educ. Eval. Health Prof. 2014, 11, 20. [CrossRef] [PubMed]

29. Nguyen, Q.D.; Fernandez, N.; Karsenti, T.; Charlin, B. What is reflection? A conceptual analysis of major definitions and a proposal of a five-component model. Med. Educ. 2014, 48, 1176-1189. [CrossRef] [PubMed]

30. McGillivray, J.; Gurtman, C.; Boganin, C.; Sheen, J. Self-practice and self-reflection in training of psychological interventions and therapist skills development: A qualitative meta-synthesis review. Aust. Psychol. 2015, 50, 434-444. [CrossRef]

31. Miraglia, R.; Asselin, M.E. Reflection as an educational strategy in nursing professional development: An integrative review. J. Nurses Prof. Dev. 2015, 31, 62-72. [CrossRef] [PubMed]

32. Ng, S.L.; Kinsella, E.A.; Friesen, F.; Hodges, B. Reclaiming a theoretical orientation to reflection in medical education research: A critical narrative review. Med. Educ. 2015, 49, 461-475. [CrossRef] [PubMed]

33. Tsingos, C.; Bosnic-Anticevich, S.; Lonie, J.M.; Smith, L. A model for assessing reflective practices in pharmacy education. Am. J. Pharm. Educ. 2015, 79, 124. [CrossRef] [PubMed]

34. Tsingos, C.; Bosnic-Anticevich, S.; Smith, L. Learning styles and approaches: Can reflective strategies encourage deep learning? Curr. Pharm. Teach. Learn. 2015, 7, 492-504. [CrossRef]

35. Van Roy, K.; Vanheule, S.; Inslegers, R. Research on balint groups: A literature review. Patient Educ. Couns. 2015, 98, 685-694. [CrossRef] [PubMed]

36. Atkins, S.; Murphy, K. Reflection: A review of the literature. J. Adv. Nurs. 1993, 18, 1188-1192. [CrossRef] [PubMed]

37. Carkhuff, M.H. Reflective learning: Work groups as learning groups. J. Contin. Educ. Nurs. 1996, 27, $209-214$. [PubMed]

38. Heath, H. Keeping a reflective practice diary: A practical guide. Nurse Educ. Today 1998, 18, 592-598. [CrossRef]

39. Mackintosh, C. Reflection: A flawed strategy for the nursing profession. Nurse Educ. Today 1998, 18, 553-557. [CrossRef]

40. Rooke, T.R. A critical review of reflective practice in its role towards personal and professional development. J. R. Nav. Med. Serv. 1998, 84, 66-70. [PubMed]

41. Clouder, L. Reflective practice in physiotherapy education: A critical conversation. Stud. High. Educ. 2000, 25, 211-223. [CrossRef]

42. Donaghy, M.E.; Morss, K. Guided reflection: A framework to facilitate and assess reflective practice within the discipline of physiotherapy. Physiother. Theory Pract. 2000, 16, 3-14. [CrossRef] 
43. Cotton, A.H. Private thoughts in public spheres: Issues in reflection and reflective practices in nursing. J. Adv. Nurs. 2001, 36, 512-519. [CrossRef] [PubMed]

44. Griffiths, C. Remembrance of things past: The utilisation of context dependant and autobiographical recall as means of enhancing reflection on action in nursing. Nurse Educ. Today 2004, 24, 344-349. [CrossRef] [PubMed]

45. Schutz, S. Reflection and reflective practice. Community Pract. 2007, 80, 26-29. [PubMed]

46. Fowler, J. Experiential learning and its facilitation. Nurse Educ. Today 2008, 28, 427-433. [CrossRef] [PubMed]

47. Sandars, J. The use of reflection in medical education: Amee guide No. 44. Med. Teach. 2009, 31, $685-695$. [CrossRef] [PubMed]

48. Koole, S.; Dornan, T.; Aper, L.; Scherpbier, A.; Valcke, M.; Cohen-Schotanus, J.; Derese, A. Factors confounding the assessment of reflection: A critical review. BMC Med. Educ. 2011, 11, 104. [CrossRef] [PubMed]

49. Bernard, A.W.; Gorgas, D.; Greenberger, S.; Jacques, A.; Khandelwal, S. The use of reflection in emergency medicine education. Acad. Emerg. Med. 2012, 19, 978-982. [CrossRef] [PubMed]

50. Murdoch-Eaton, D.; Sandars, J. Reflection: Moving from a mandatory ritual to meaningful professional development. Arch. Dis. Child. 2014, 99, 279-283. [CrossRef] [PubMed]

51. Wald, H.S. Refining a definition of reflection for the being as well as doing the work of a physician. Med. Teach. 2015, 37, 696-699. [CrossRef] [PubMed]

52. Dewey, J. How We Think, a Restatement of the Relation of Reflective Thinking to the Educative Process; D.C. Heath and Company: Boston, MA, USA; New York, NY, USA, 1933.

53. Argyris, C.; Schön, D.A. Theory in Practice: Increasing Professional Effectiveness; Jossey-Bass: San Francisco, CA, USA, 1974.

54. Argyris, C.; Schön, D.A. Organizational Learning: A Theory of Action Perspective; Addison-Wesley Reading: MA, USA, 1978.

55. Boyd, E.M.; Fales, A.W. Reflective learning-Key to learning from experience. J. Humanist. Psychol. 1983, 23, 99-117. [CrossRef]

56. Kolb, D.A. Experiential Learning: Experience as the Source of Learning and Development; Prentice-Hall: Englewood Cliffs, NJ, USA; London, UK, 1984.

57. Boud, D.; Keogh, R.; Walker, D. Reflection, Turning Experience into Learning; Kogan Page; Nichols Pub.: London, UK; New York, NY, USA, 1985.

58. Mezirow, J. Transformative Dimensions of Adult Learning, 1st ed.; Jossey-Bass: San Francisco, CA, USA, 1991.

59. Van Manen, M. Linking ways of knowing with ways of being practical. Curric. Inq. 1977, 6, $205-228$. [CrossRef]

60. Van Manen, M. On the epistemology of reflective practice. Teach. Teach. Theory Pract. 1995, 1, 33-50. [CrossRef]

61. Turner, S. Safeguarding children training in adult mental health care. Ment. Health Pract. 2009, 12, $28-32$. [CrossRef]

62. Kemp, P.; Rooks, J.; Mess, L. Work-based learning with staff in an acute care environment: A project review and evaluation. Ment. Health Pract. 2009, 12, 31-35. [CrossRef]

63. Jenkins, E. Using cooperative inquiry and clinical supervision to improve practice. Br. J. Community Nurs. 2007, 12, 63-69. [CrossRef] [PubMed]

64. Ménard, L.; Ratnapalan, S. Reflection in medicine: Models and application. Can. Fam. Phys. 2013, 59, 105-107.

65. Sobral, D.T. Medical students' reflection in learning in relation to approaches to study and academic achievement. Med. Teach. 2001, 23, 508-513. [CrossRef] [PubMed]

66. Mamede, S.; Schmidt, H.G. The structure of reflective practice in medicine. Med. Educ. 2004, 38, $1302-1308$. [CrossRef] [PubMed]

(c) 2016 by the author; licensee MDPI, Basel, Switzerland. This article is an open access article distributed under the terms and conditions of the Creative Commons Attribution (CC-BY) license (http://creativecommons.org/licenses/by/4.0/). 